\title{
The influence of hyperthyroidism on implant restoration treatment outcome
}

\author{
Suhandi Sidjaja, Soenawan, ${ }^{*}$ Retno Pontjowulandari, ${ }^{*}$ Ira Tanti ${ }^{*}$
}

\begin{abstract}
Abstrak
Informasi yang terkait dengan perawatan restorasi implan tulang pada penderita kehilangan gigi dengan kelainan hipertiroid masih sangat terbatas. Laporan kasus ini menyajikan pembuatan restorasi implan tulang gigi pada pasien dengan riwayat hipertiroid. Dalam laporan kasus ini seorang laki laki berusia 60 tahun dengan hipertiroid datang ke klinik Prostodonsia FKG UI untuk memperbaiki protesa yang kurang nyaman. Setelah dievaluasi secara cermat, pada penderita kami buatkan Implant-Tissue-Supported Overdenture (4 implan) untuk merehabilitasi rahang atas tak bergigi, dan 2 Implant-Tissue-Supported Fixed Partial Denture untuk kehilangan gigi Kennedy klas I rahang bawah. Evaluasi jangka pendek berdasarkan kriteria Buser memperlihatkan hasil positif. (Med J Indones 2006; 15:191-5)
\end{abstract}

\begin{abstract}
There is limited information about bone implant restoration treatment on edentulous patient with hyperthyroidism. This clinical report is presenting the making of dental bone implant restoration on patient with hyperthyroidism history. A 60 years old male patient with hyperthyroidism came to Prosthodontic Clinic Faculty of Dentistry University of Indonesia to improve his ailing denture. After comprehensive evaluation we treated the patient with Implant-Tissue-Supported Overdenture (4 Implants) for rehabilitating upper edentulous jaw, and 2 Implant-Tooth-Supported Fixed Partial Denturesfor rehabilitating Kennedy class II lower edentulous jaw respectively. Short term clinical and radiographic evaluation based on Buser's criteria showed positive result. (Med J Indones 2006; 15:191-5)
\end{abstract}

Keywords: Hyperthyroidsm, implant restoration.

There are several methods to replace missing tooth either with conventional dentures (fixed or removable) or implant dentures (STI=Single Tooth Implant, ISFPD=Implant Supported Fixed Partial Denture, ITSFPD=Implant Tooth Supported Fixed Partial Denture and $\mathrm{IOD}=$ Implant Overdenture). Conventional denture has limited indication and outcome quality, whereas implant denture provides advantage characteristics in function, stability, and comfort and can replace one to entire missing tooth as long as it is supported by healthy oral (bone quality and quantity) and general status. The outcome of implant restoration depends on many factors, such as, treatment designs (implant and prosthesis), clinical execution, laboratory quality, occlusion, and patient's cooperativeness. Hyperthyroidism is an endocrine disease with excessive production of thyroxin in the thyroid gland, which causes a generalized increase in the metabolic rate of all body tissue, resulting in tachycardia, increased blood pressure,

\footnotetext{
* Department of Prosthodontic, Faculty of Dentistry, University of Indonesia, Jakarta, Indonesia
}

sensitivity to heat irritability, decrease in bone density and loss of some area of edentulous bone. ${ }^{1}$ Therefore bone implant treatment on edentulous patient with hyperthyroidism history is a compromised treatment due to bone condition (bone loss and osteoporosis). However when hyperthyroidism is under control, with normal thyroid function and no symptoms of disease within the past 6 months, a normal protocol may be used for all dental implant surgery and restorative procedures. ${ }^{2}$ The success rate of osseointegration phase is $97.8 \% .^{3}$ The purpose of this clinical report is to evaluate the outcome of implant restoration treatment on patient with hyperthyroidism hystory.

\section{METHODS}

A 60 years old male lecturer with upper edentulous and lower bilateral free end partial edentulous came to Prosthodontic Department clinic Faculty of Dentistry University of Indonesia, to improve his ill fitting dentures. Clinical and radiographic finding showed; patient wore unstable narrow upper acrylic full denture and double free-end acrylic lower denture; 
excessive flabby mucosa on upper anterior and lower left posterior jaws; compromised bone quantity and quality on upper edentulous jaw; large occlusal space (distance is measured from upper ridge crest-lower

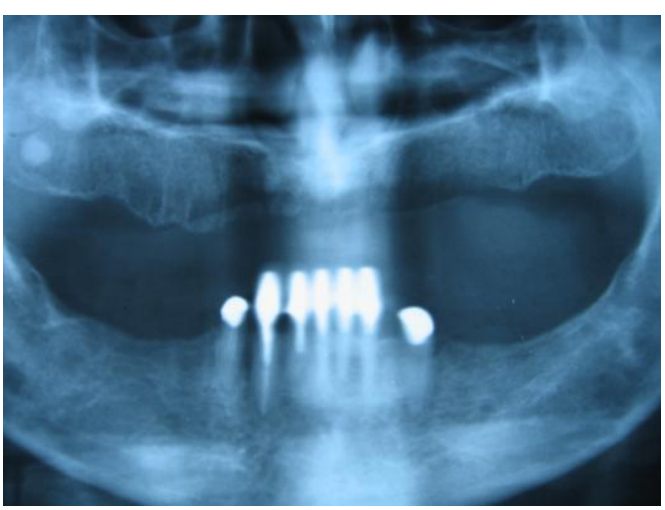

Figure 1. Before treatment (February 2004)

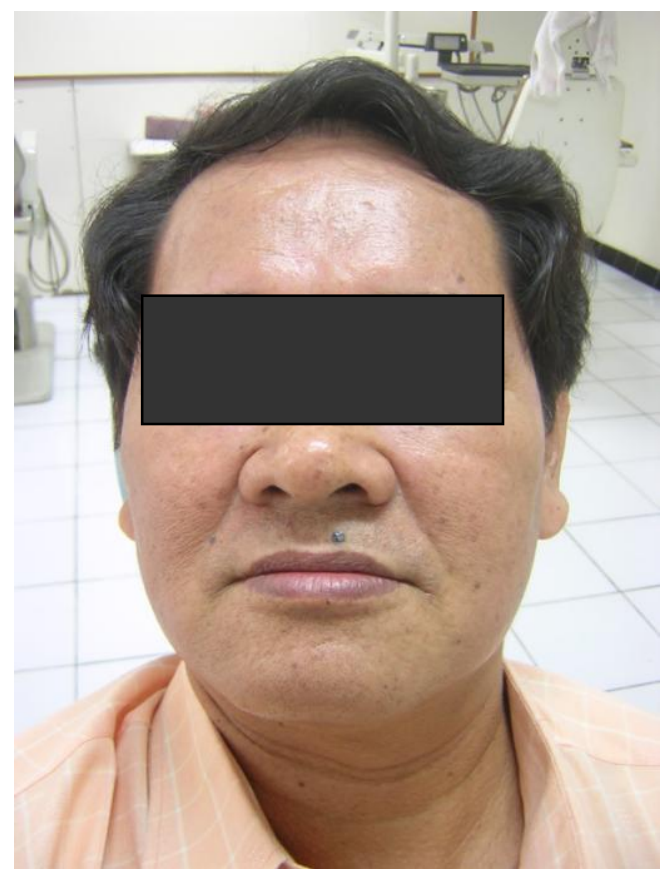

Figure 3. Patient's appearance in his old upper and lower denture occlusal surface), $15 \mathrm{~mm}, 16 \mathrm{~mm}$ and $11 \mathrm{~mm}$ respectively on anterior, left, and right posterior. It was indicated from patient's appearance that vertical dimension was reduced (Figure. 1, 2, 3, and 4).

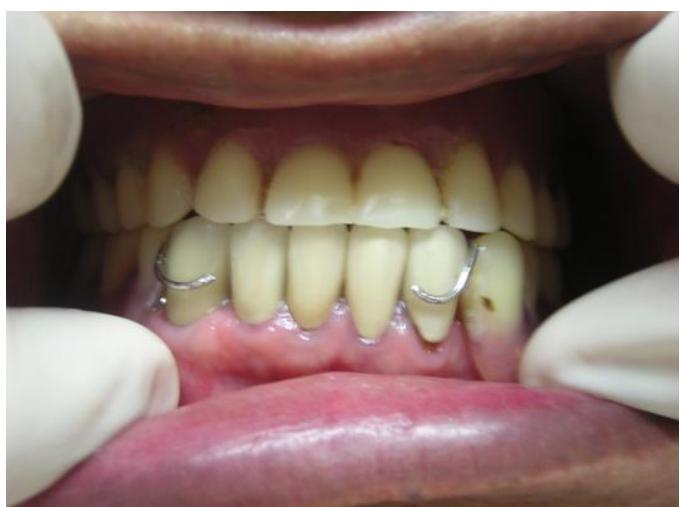

Figure 2. Upper and Lower old denture

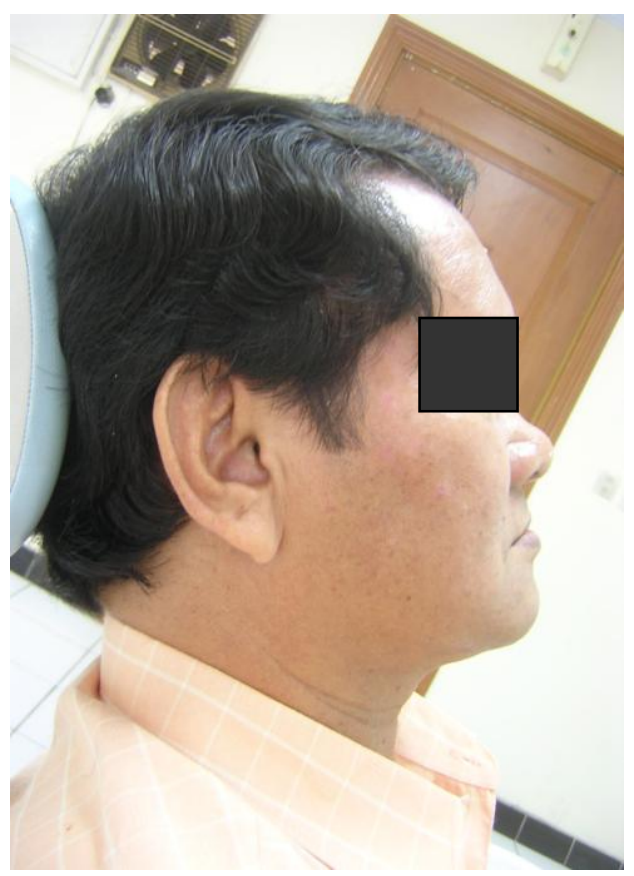

Figure 4. Patient's profile in his old upper and lower denture 
Treatment plans were based on comprehensive medical and dental review, which consisted of mucosa plasty for upper anterior and lower left posterior, ImplantTissue-Supported Overdenture (four implants) and two Implant Tooth Supported Fixed Partial Dentures for upper and lower jaws respectively. Implant denture designs were based on stability, bone volume and quality, and patient's financial status. Patient had been well-informed with the risks associated with the treatment and had given his consent to accept this treatment plans. Premedication for minor surgery was given prior to implant placement. Implants length, location, and direction were decided based on panoramic (Yoshida) and periapical (Asahi and Digore) radiographs,

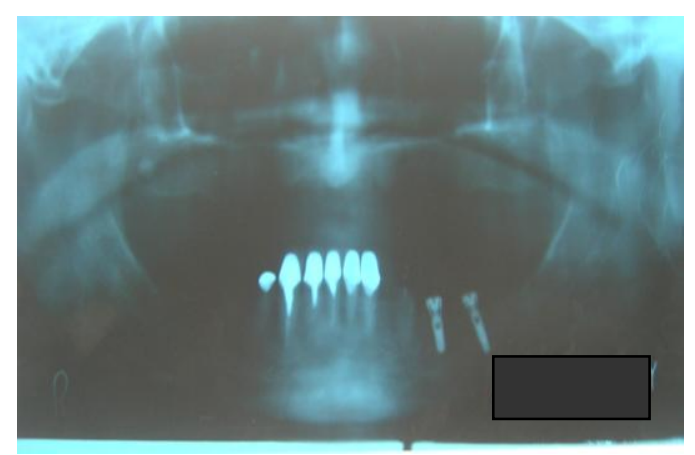

Figure 5. November 2004

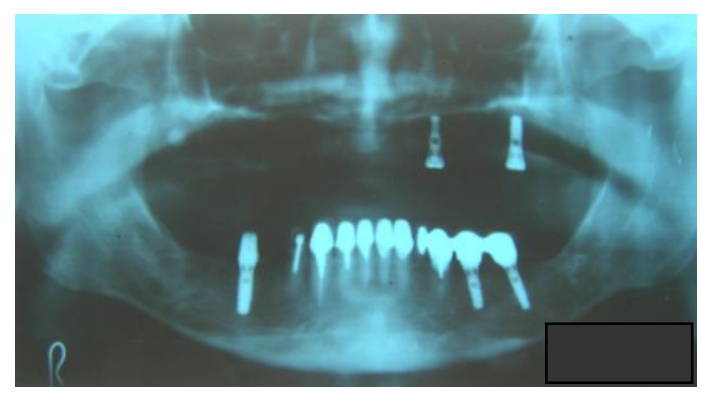

Figure 7. July 2005

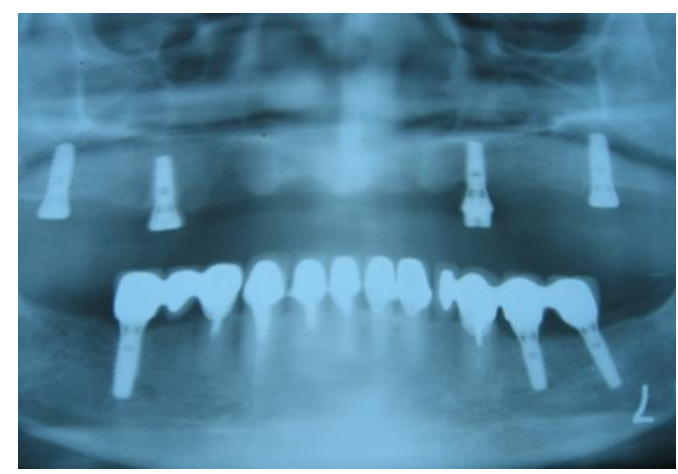

Figure 9. After treatment (2005) as well as study cast and clinical inspections. Osteotomy was performed according to Branemark's standard ${ }^{4}$ and implant manufacturer instruction. Two root form implants were placed on regions of 35 and 36 on Nov 9,2004 (Figure 5); one root form implant was placed on region 46 on March 19,2005 (Figure 6); two root form implants were placed on region 23 and 27 on June 25, 2005 (Figure 7); two root form implants were placed on region 14 and 17 on August 6, 2005 (Figure 8); one PFM Implant-Tooth-Supported Fixed Partial Denture $(33,34,35,36)$ was constructed on February 4, 2005; and one PFM Implant-Tooth-Supported Fixed Partial Denture $(44,45,46)$ was constructed on August 30, 2005 (Figure 9,10).

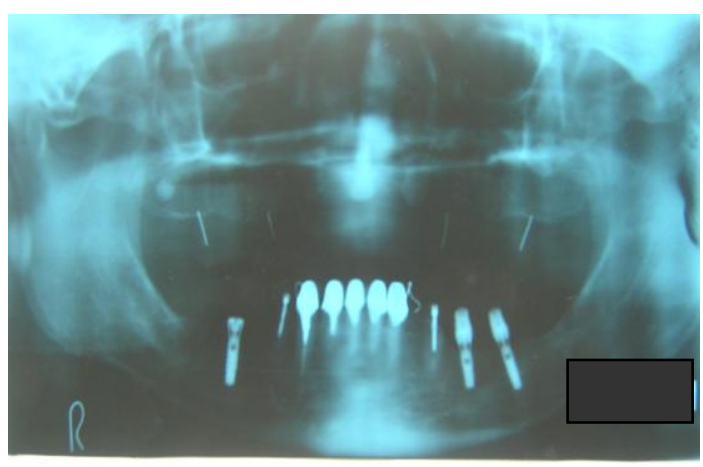

Figure 6. Mei 2005

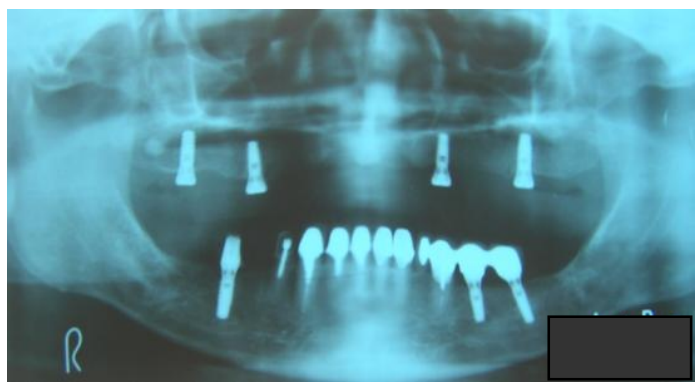

Figure 8. August 2005

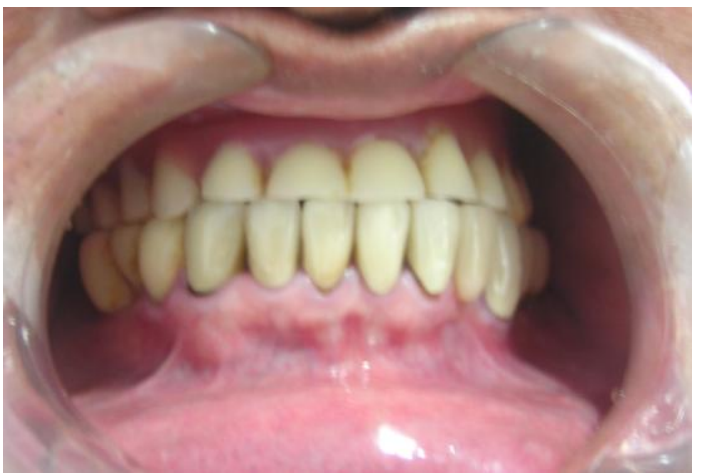

Figure 10. Upper old full denture and lower new two ITSFPDs. 
All superstructures were designed with minimum occlusal and lateral load. The upper old denture was modified and adjusted to 4 implant healing screws to act as temporary overdenture. The permanent overdenture was constructed on February 6, 2006, vertical dimension was increased $4 \mathrm{~mm}$ from the previous denture. Labial flange was thickened according to neutral zone. Low incline cusp, disclusion scheme was selected. Survival evaluation was performed according to Buser's criteria. ${ }^{5}$

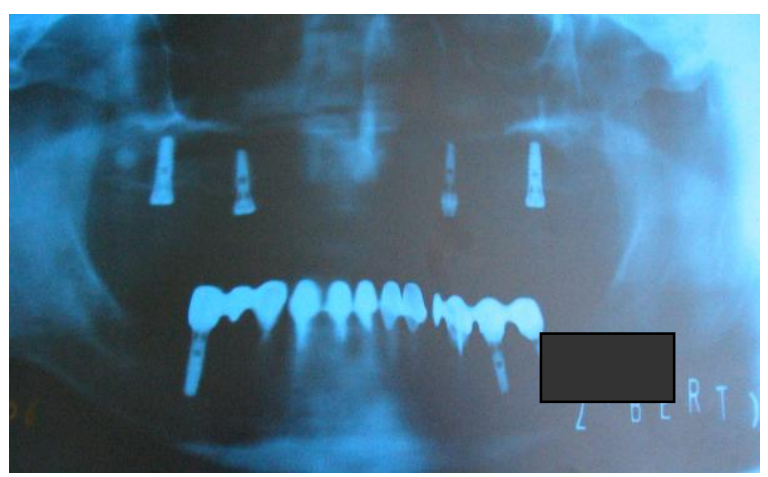

Figure 11. After treatment (2006)

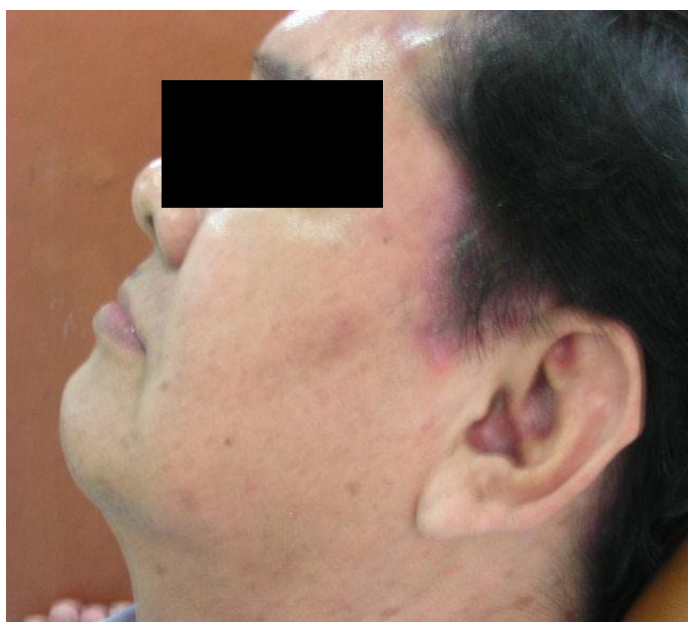

Figure 13. Patient's profile in his new upper and lower denture

\section{RESULTS}

After 3 and 6 months all implant-bone osseointegrations on lower and upper jaws, respectively, were successful (Figure 11). No signs of mucosal inflammation, altered sensation or other abnormalities were detected in all implants (Figure 12). Two lower PFM ITSFPD were well function up to the present day. The temporary and permanent overdentures showed improved stability and comfort, as well as facial and lip support (Figure 13, 14).

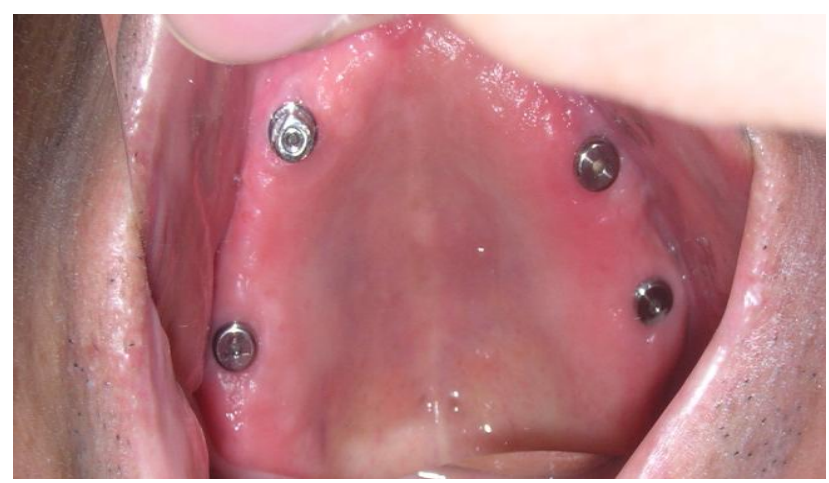

Figure 12. Four implant on upper jaw

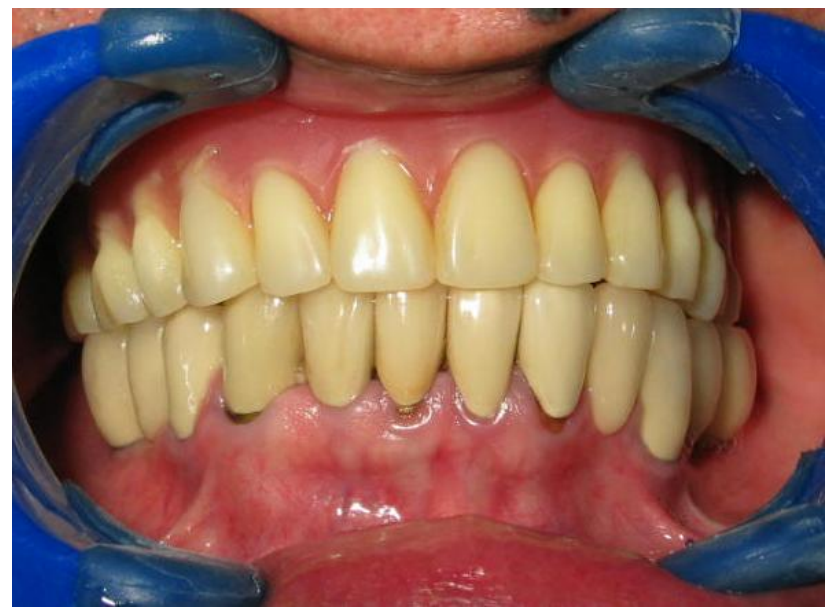

Figure 14. Upper and lower new denture 


\section{DISCUSSION}

Bone implant treatment on edentulous patient with hyperthyroidism history is a compromised treatment. ${ }^{1}$ In this case hyperthyroidism is already under control, with normal thyroid function and no symptoms of disease within the past one year. The main problem of this patient was his difficulty in speaking due to unstable upper denture. As lecturer patient needs a stable denture by which he could speak clearly and fluently to the students. Excessive bone resorption and hypersensitivity on upper jaw were the reason for upper denture instability and inadequate retention.

Two ITSFPD were selected for lower jaw because of compromised bone volume, cost effectiveness, and high survival rate. ${ }^{6}$ The ITSFPD on posterior left and right lower jaw increases patient's comfort on speaking and masticating, and reduces the bone resorption rate. Implant-Tissue-Supported Overdenture was selected for upper edentulous jaw instead of fixed denture or Implant-Supported Overdenture because of compromised bone quality and volume, cost effectiveness, in order to minimized vertical and lateral load, and to fulfill facial and lip support.

The upper Implant-Tissue-Supported Overdenture is a complex restoration, as well as compromising boneimplant stability due to bone resorption pattern, proximity to maxillary sinuses, and nasal cavity. ${ }^{7,8}$ Therefore scrutinized case selection is needed, and implant placement and restorative construction should be done properly and carefully. Low cusp inclined, disclusion, and shortened dental arch are important factors to minimize mastication force.

\section{CONCLUSION}

Short term clinical and radiographic evaluation based on Buser's criteria shows good prognosis in implant restoration treatment on patient with hyperthyroidism hystory. The treatment plan and clinical execution was done carefully and properly. Further evaluation and study are needed for medium and long term prognosis.

\section{REFERENCES}

1. White SC, Pharoah MJ. Systemic Diseases Manifested in the Jaws. Oral Radiology Principles and Interpretation. $5^{\text {th }}$ Ed. Mosby Inc. 2004: 522.

2. Fagan MJ, Ismail JYH, Meffert RM, Fagan MJ. Implant Prosthodontics. Surgical and Prosthetic Techniques for Dental Implant. Year Book Medical Publishers, Inc.1990 56-7.

3. Van Steenberghe D, Jacob R, Desnyder M, Maffei G, Quirynen M. The relative impact of local and endogenous patient-related factors on implant failure up to abutment stage Clin Oral Implants Res.2002;13(6);617-22.

4. Branemark PI, Zarb GA, Albrektsson T. Tissue-Integrated Prostheses: Osseointegration in Clinical Dentistry. Chicago; Quintessence Publishing Co;1985:211-4.

5. Buser D, Weber HP, Lang NP. Tissue integration of nonsubmerged implant. One year results of a prospective study with 100 ITI hollow-screw and hollow-cylinder implants. Clinical Oral Implants Research 1:33-40

6. Sijaya S. The Efficiency of Implant Restoration Treatment. $19^{\text {th }}$. International Symposium of AOIA, Jakarta, 12-13 December 2003:1-4.

7. Zitzmann NU, Marinello CP. Treatment plan for restoring the edentulous maxilla with implant supported restorations: Removable overdenture versus fixed partial design. J Prosthet Dent 1999;82:188-96.

8. Hobo S, Ichida E, Carcia LT. Osseointegration and Occlusal Rehabilitation. Quintessence Publishing Company 1990. Tokyo, Berlin, Chicago, London, Sao Paulo, Hongkong: 60-2. 